SUSTAINABLE ENVIRONMENT AGRICULTURAL SCIENCE (SEAS)

https:/ejournal.warmadewa.ac.id/index.php/seas/index

E-mail: info.seas@warmadewa.ac.id

Volume 1, Issue 2, October 2017, Pages: 32-38

Received: July 10, 2017

Revised: August 22, 2017

Accepted: October 14, 2017

\title{
The Influence of Wheat Flour and Tapioca Comparison Against Characteristics of The Chips Beluntas Leaves During Storage
}

\author{
Luh Suriati, I Nyoman Rudianta, Putu Candra, I Gusti Ayu Sukmawati \\ Food Science and Technology Department, Faculty of Agriculture, Warmadewa University, Denpasar, Bali, \\ Indonesia \\ E-mail: suryati_luh@yahoo.com
}

Abstract

This study aims to know the comparison of wheat flour and tapioca flour in order to make the right ones not quickly wilted. Beluntas is herbs containing chemical compounds including i.e. phenol, alkaloids, tannins, essential oils that act as an antioxidant, anti-bacterial and also helps eliminate body odor. Leaf beluntas, when made into chips will be able to add diversification food products. Surely this will be very interesting for new innovations of food and expected to get the international market. Characteristics of the chips beluntas leaves can still be maintained with tapioca flour: comparison of 30:70 at 8 days storage with objective observations of water levels $21.50 \%$, carbohydrates $8.74 \%$, proteins $2.73 \%$, fat $18.90 \%$, levels of phenol $1485.33 \mathrm{mg} / \mathrm{kg} \mathrm{drag}$ power antioxidant $0.06 \%$ ). While the subjective observations (color, aroma, flavor, texture and overall admissions) 6.0-6.7 with criteria like-love.

Keywords: wheat flour, tapioca, chips beluntas, storage

\section{Introduction}

The development of human civilization rapidly growth demands a variety of efforts to maintain and promote health by utilizing the natural resources existing in the vicinity. This is because synthetic chemicals that circulate in the community generally have side effects that endanger health. Currently a variety of efforts underway to develop food products that can be relied upon as custodians of the health and fitness of the body. Even if it is possible these products could cure certain diseases. One of them is the beluntas leaves processed into chips leaves beluntas. Beluntas is herbs containing chemical compounds including i.e. phenol, alkaloids, tannins, essential oils that act as an antioxidant, anti-bacterial and also helps eliminate body odor.

In terms of dairy, leaves beluntas (Pluchea indica L) chips more practical and economical value when compared to the use of either directly or boiled to drink its water. Chips leave beluntas yet so well known community when compared to such ilk crackers chips spinach that has been popular recently circulated in the market, it needs to be done to various attempts to develop it. Leaf beluntas, when made into chips will be able to add diversification food products. Surely this will be very interesting for new innovations in the world of food and expected to get into the market is international. In the manufacture of chips are frequent problems of fast chips it withers or not the crisp because the comparison of flour used is not appropriate. In addition to the prolonged storage of chips is often very short. To know these things need to be done the research on the comparison of flour used and long storage.

This study aims to know the comparison of wheat flour and tapioca flour in order to make the 
right ones not quickly wilted. Knowing the long holding to make beluntas in polyethylene packaging. The benefits of research expected to support other studies regarding the beluntas and is expected to be able to provide information to the public regarding the use of the comparison of wheat flour and tapioca flour are right for beluntas, so that leaves the chips are not quickly withering and can extend shelf life.

\section{Material and Methods}

\subsection{Material}

The materials used include: leaves beluntas who are still young and fresh, flour, tapioca flour, packaging plastic polyethylene, salt, turmeric, coriander, garlic. Implementation research (Figure 1): leaves beluntas weighed, then washed and then drained. After the materials and tools ready, wheat flour and tapioca flour mixed with herbs appropriate treatment (salt, garlic, turmeric, coriander) and water until dough forms. Beluntas leaves and then dipped in a batter that has been prepared, and then fried at $163{ }^{\circ} \mathrm{C}$ for $1 \mathrm{~min}$, once cooked then drained in the machine more spin. Chips that have been beluntas cold leaves packed in a plastic polyethylene 0.02 size and stored at room temperature appropriate treatment.

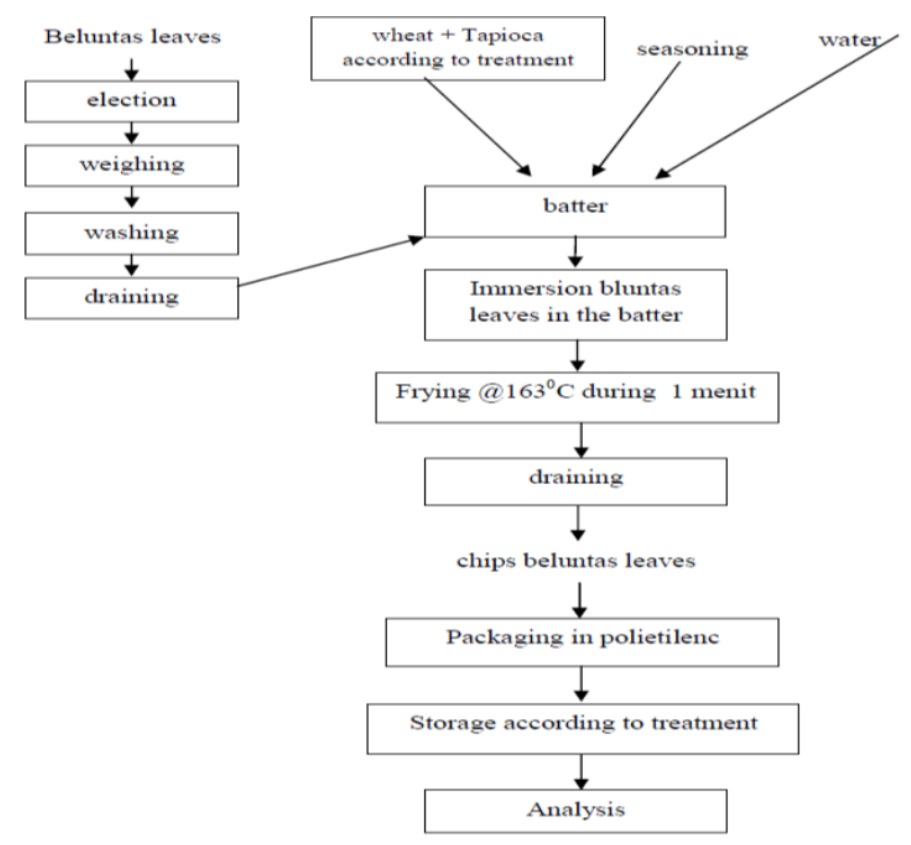

Figure 1. Flowchart to make research beluntas

\subsection{Methods}

This study used a Randomized Complete Design (RCD) with factorial pattern with two factors of treatment and 2 times repeats include: comparison of wheat flour and tapioca flour, which consists of three levels, namely $\mathrm{T}_{1}(50 \%: 50 \%), \mathrm{T}_{2}: 30 \%(70 \%), \mathrm{T}_{3}: 10 \%(90 \%)$. Prolonged storage that consists of 4 levels, namely $\mathrm{M}_{1}(2$ days $), \mathrm{M}_{2}(4$ days $), \mathrm{M}_{3}(6$ days $), \mathrm{M}_{4}(8$ days $)$. The combination Treatment becomes $3 \times 4=12$ combination. Each treatment was repeated twice until retrieved 24 unit experiment.

\subsection{Observation and analysis}

The observed parameters are moisture, carbohydrates, fats, proteins, the active component of phenol, power drag antioxidant and organoleptic against color, aroma, flavor, texture and overall ac- 
ceptance of the done by 15 panelists using a hedonic scale and later transformed to a numeric scale.

\subsection{Statistical Analysis}

Data obtained from the results of the research will be analyzed by analysis of variance. When in the analysis range obtained a real treatment influences continued with the least significant difference test (LSD) to find out a different pair, whereas the subjective data to proceed with the test Duncan.

\section{Results and Discussion}

\subsection{Moisture Content}

Based on the analysis of the spectrum of visible fingerprints comparison of wheat flour: tapioca and retention, as well as their interaction effect, is evidence against moisture content of chips leaves beluntas. The highest water levels obtained at treatment comparison: tapioca flour 10:90\% retention 25.82 i.e. 8 days. While low in comparison: tapioca flour $30: 70$ i.e. $17.05 \%$ retention of 2 days.

Table 1

Influence of Prolonged Storage of Flour and Comparison Against The Moisture Content of Chips Leaves Beluntas $(\%)$

\begin{tabular}{lllll}
\hline $\begin{array}{l}\text { Comparison of wheat } \\
\text { flour and Tapioca }(\%)\end{array}$ & \multicolumn{4}{l}{ Prolonged storage (days) } \\
\cline { 2 - 5 } & $\mathrm{M}_{1}$ & $\mathrm{M}_{2}$ & $\mathrm{M}_{3}$ & $\mathrm{M}_{4}$ \\
\hline \multirow{2}{*}{$\mathrm{T}_{1}$} & $17.30 \mathrm{a}$ & $18.36 \mathrm{~b}$ & $20.62 \mathrm{c}$ & $21.49 \mathrm{~d}$ \\
& $\mathrm{a}$ & $\mathrm{a}$ & $\mathrm{b}$ & $\mathrm{b}$ \\
$\mathrm{T}_{2}$ & $17.06 \mathrm{a}$ & $18.95 \mathrm{a}$ & $19.55 \mathrm{~b}$ & $20.42 \mathrm{~b}$ \\
& $\mathrm{a}$ & $\mathrm{a}$ & $\mathrm{a}$ & $\mathrm{a}$ \\
$\mathrm{T}_{3}$ & $19.33 \mathrm{a}$ & $20.65 \mathrm{a}$ & $20.09 \mathrm{a}$ & $25.82 \mathrm{~b}$ \\
& $\mathrm{~b}$ & $\mathrm{~b}$ & $\mathrm{~b}$ & $\mathrm{c}$ \\
\hline
\end{tabular}

Different letters below the average value in the same column shows the very real influence $(P>0.01)$

According to [1], starch has the ability to bind water because the number of hydroxyl groups is very large. The growing number of tapioca flour, then more and more water is absorbed so that the moisture content is higher. Foodstuffs that have a high water content will tend to be fast compared to food that has low water content.

\subsection{Carbohydrate Levels}

Analysis of the comparative treatment shows the range prints all purpose flour: tapioca flour and retention, as well as interaction, had no effect on the real levels of carbohydrate chips leaves beluntas. Tapioca flour is a form of carbohydrate. The larger the addition of tapioca flour causes the higher carbohydrate [2]. The rising water levels of a food than the content of compounds such as proteins, fats, carbohydrates will progressively decrease.

Table 2

Influence of Prolonged Storage of Flour and Comparison Against Levels of Carbohydrate Chips Leaves Beluntas $(\%)$

\begin{tabular}{llllll}
\hline \multirow{2}{*}{$\begin{array}{l}\text { Comparison of wheat flour } \\
\text { and Tapioca (\%) }\end{array}$} & \multicolumn{2}{l}{ Prolonged storage (days) } & \multirow{2}{*}{ Average } \\
\cline { 2 - 5 } & $\mathrm{M}_{1}$ & $\mathrm{M}_{2}$ & $\mathrm{M}_{3}$ & $\mathrm{M}_{4}$ & \\
\hline $\mathrm{T}_{1}$ & 8.48 & 8.21 & 7.67 & 6.99 & $7.48 \mathrm{a}$ \\
$\mathrm{T}_{2}$ & 8.51 & 8.30 & 6.68 & 6.43 & $7.84 \mathrm{a}$ \\
$\mathrm{T}_{3}$ & 11.86 & 7.54 & 7.31 & 6.99 & $8.42 \mathrm{a}$ \\
\hline Average & $8.74 \mathrm{a}$ & $8.18 \mathrm{a}$ & $6.91 \mathrm{a}$ & $6.91 \mathrm{a}$ & \\
\hline
\end{tabular}




\subsection{Levels of Protein}

Analysis of prints variety shows the comparison of wheat flour: tapioca, long storage, and their interaction suggests the influence of unreal. The flaky crispness is determined by the levels of protein and moisture content in the growing number of chips, tapioca flour is added, then the protein will be even greater, causing chips are getting crispy. The higher the moisture content, protein levels tend to be on the decline.

Table 3

Influence of Prolonged Storage of Flour and Comparison Against The Protein Chips Leaves Beluntas (\%)

\begin{tabular}{llllll}
\hline Comparison of wheat flour and & \multicolumn{2}{l}{ Prolonged storage (days) } & \multicolumn{2}{l}{ Average } \\
\cline { 2 - 5 } tapioca (\%) & $\mathrm{M}_{1}$ & $\mathrm{M}_{2}$ & $\mathrm{M}_{3}$ & $\mathrm{M}_{4}$ & $2.45 \mathrm{a}$ \\
$\mathrm{T}_{1}$ & 2.73 & 2.61 & 2.58 & 2.39 & $2.55 \mathrm{a}$ \\
$\mathrm{T}_{2}$ & 2.61 & 2.39 & 2.39 & 2.39 & $2.58 \mathrm{a}$ \\
$\mathrm{T}_{3}$ & 2.61 & 2.61 & 2.61 & 2.39 & $2.47 \mathrm{a}$ \\
\hline Average & $2.58 \mathrm{a}$ & $2.54 \mathrm{a}$ & $2.53 \mathrm{a}$ & \\
\hline
\end{tabular}

\subsection{Fat Content}

Analysis of the prints range indicates that the treatment comparison: tapioca flour, long storage and treatment interactions show no real effect against fat levels beluntas chips. According to [3], crisps are a snack food crackers or crusts that are crisp, crunchy, and high-fat content. According to [4], the fat content of refined products will be increased with the addition of carbs, lean protein, whole grains, flour and skim.

The high-fat content, resulting in faster product experience rancidity, crispness is reduced, so the reduced consumer acceptance of product because of such appearance of an oily product [5].

Table 4

Influence of Prolonged Storage of Flour and Comparison of Fat Levels of Chips Leaves Beluntas (\%)

\begin{tabular}{llllll}
\hline Comparison of wheat & \multicolumn{2}{l}{ Prolonged storage (days) } & \multicolumn{2}{l}{ Average } \\
\cline { 2 - 5 } flour and Tapioca (\%) & $\mathrm{M}_{1}$ & $\mathrm{M}_{2}$ & $\mathrm{M}_{3}$ & $\mathrm{M}_{4}$ & $19.76 \mathrm{a}$ \\
\hline $\mathrm{T}_{1}$ & 21.07 & 19.97 & 19.02 & 18.99 & $22.66 \mathrm{a}$ \\
$\mathrm{T}_{2}$ & 23.81 & 23.68 & 23.63 & 23.38 & $24.13 \mathrm{a}$ \\
$\mathrm{T}_{3}$ & 23.95 & 23.88 & 23.31 & 22.52 & \\
\hline Average & $22.92 \mathrm{a}$ & $22.04 \mathrm{a}$ & $21.89 \mathrm{a}$ & $21.88 \mathrm{a}$ & \\
\hline
\end{tabular}

\subsection{Total Phenol}

Analysis of the treatment of visible range prints all purpose flour: tapioca and retention, as well as their interaction effect, is very real to the total phenol. The highest levels of total phenols obtained from treatment comparison: tapioca flour 50:50 long storage of 2 days of $1148.33 \mathrm{mg} / \mathrm{kg}$. While the total phenol lowest of tapioca flour: comparison of $30: 70$ long 8 days storage of $958.71 \mathrm{mg} / \mathrm{kg}$. Phenol has acidic properties, easily oxidized, volatile. Phenol levels will decrease with the washing, boiling and advanced food processing [6].

Table 5

Comparison of Influence of Flour and Prolonged Storage to The Total Phenol Chips Leaves Beluntas (mg/kg)

\begin{tabular}{lllll}
\hline \multirow{2}{*}{$\begin{array}{l}\text { Comparison of wheat flour } \\
\text { and Tapioca (\%) }\end{array}$} & \multicolumn{5}{l}{ Prolonged storage (days) } \\
\cline { 2 - 5 } & $\mathrm{M}_{1}$ & $\mathrm{M}_{2}$ & $\mathrm{M}_{3}$ & $\mathrm{M}_{4}$ \\
\hline \multirow{2}{*}{$\mathrm{T}_{1}$} & $1485.33 \mathrm{~d}$ & $1164.93 \mathrm{c}$ & $1062.04 \mathrm{~b}$ & $1028.66 \mathrm{a}$ \\
& $\mathrm{b}$ & $\mathrm{c}$ & $\mathrm{b}$ & $\mathrm{b}$ \\
$\mathrm{T}_{2}$ & $1114.85 \mathrm{~d}$ & $1030.87 \mathrm{c}$ & $997.51 \mathrm{~b}$ & $958.71 \mathrm{a}$ \\
& $\mathrm{a}$ & $\mathrm{a}$ & $\mathrm{a}$ & $\mathrm{a}$ \\
$\mathrm{T}_{3}$ & $1149.77 \mathrm{c}$ & $1094.32 \mathrm{~b}$ & $1068.61 \mathrm{a}$ & $1067.87 \mathrm{a}$ \\
& $\mathrm{a}$ & $\mathrm{b}$ & $\mathrm{b}$ & $\mathrm{b}$ \\
\hline \multicolumn{4}{c}{ Different letters below the average value in the same column shows the very real influence $(\mathrm{P}>0.01)$}
\end{tabular}




\subsection{Power Drag Antioxidant}

Analysis of the prints range against cruising drag antioxidant suggests that comparison: tapioca flour and retention as well as their interaction effect very real power against drag.

Table 6

Influence of Prolonged Storage of Flour and Comparison Against Percent (\%) of Drag Antioxidant Power Chips Leaves Beluntas (\%)

\begin{tabular}{lllll}
\hline $\begin{array}{l}\text { Comparison of wheat } \\
\text { flour and Tapioca (\%) }\end{array}$ & \multicolumn{4}{l}{ Prolonged storage (days) } \\
\cline { 2 - 5 } $\mathrm{M}_{1}$ & $\mathrm{M}_{2}$ & $\mathrm{M}_{3}$ & $\mathrm{M}_{4}$ \\
\hline $\mathrm{T}_{1}$ & $0.10 \mathrm{~b}$ & $0.07 \mathrm{a}$ & $0.06 \mathrm{a}$ & $0.06 \mathrm{a}$ \\
& $\mathrm{a}$ & $\mathrm{a}$ & $\mathrm{a}$ & $\mathrm{a}$ \\
$\mathrm{T}_{2}$ & $0.11 \mathrm{c}$ & $0.11 \mathrm{~b}$ & $0.10 \mathrm{a}$ & $0.09 \mathrm{a}$ \\
& $\mathrm{b}$ & $\mathrm{c}$ & $\mathrm{c}$ & $\mathrm{c}$ \\
$\mathrm{T}_{3}$ & $0.10 \mathrm{c}$ & $0.08 \mathrm{~b}$ & $0.08 \mathrm{~b}$ & $0.07 \mathrm{a}$ \\
& $\mathrm{a}$ & $\mathrm{b}$ & $\mathrm{b}$ & $\mathrm{b}$ \\
\hline
\end{tabular}

Different letters below the average value in the same column shows the very real|influence $(P>0.01)$

Drag the highest antioxidant power obtained from the comparison of the treatment: 30 tapioca flour: 70 long storage 2 days i.e. $0,11 \%$. While the lowest drag power antioxidant treatment comparison of wheat flour: tapioca 50:50 8 days retention i.e. 0.06\%. Flour is more vulnerable to experiencing a chemical reaction activity decreased antioxidant. The activity of antioxidant is the ability to capture the anti-radical compound radicals so there happen excessive production that will harm the body [8]. In addition, an antioxidant also plays in reducing the odor caused by the presence of the fat oxidation process by free radicals. Antioxidants are substances that can prevent free radical antioxidase reaction in lipid oxidation. According to [1], one of the plants containing compounds antioxidant i.e. leaf beluntas (Pluchea indica L).

\subsection{Color}

The results of the analysis show that the variety comparison of finger prints of flour and tapioca effect is real, and the old storage as well as the interaction of pointing right very real influence. The highest level of joy derived from the comparison of the panelists all purpose flour and tapioca 30 and $70 \%$ and retention 6 days and 8 days (6.00). The existence of the effect on the color of chips leaves beluntas of each treatment allegedly because white flour has gluten, gluten which is able to absorb water and is able to distribute the colors, while on a large number of tapioca flour gels formed from gelatinase, in which experiencing starch granule starch has able to reflect light so that leaves beluntas chips to seem brighter and favored by panelists.

\subsection{Aroma}

Based on her range of looks that comparison of wheat flour and tapioca effect is not real and prolonged storage of influential real as well as their interaction is not real. Favorite panelist highest obtained from a comparison of wheat flour and tapioca 30:70\% and prolonged storage of 4 days (6.20) while the lowest comparison of tapioca flour: 10: $90 \%$ and prolonged storage of 2 days (5.60). Likely this is due to a panelist has different smell parameters. Tapioca flour ratio at 30: $70 \%$ of the typical aroma of chips beluntas can be maintained so that the panelists liked it.

\subsection{Taste}

Analysis of prints variety shows a comparison of wheat flour and tapioca effect real and prolonged storage effect is not real as well as their interaction is not really against the aroma of chips 
leaves beluntas. The highest level of panelists Favorites gleaned from comparative treatment flour $30: 70 \%$ and prolonged storage 8 days (6.73) while the lowest score obtained from the comparison of flour $50: 50 \%$ and long storage of 4 days (5.93). This is possible because tapioca flour gives a more savory flavor and tasty than any other flour. The influence of value sense of fondness the products also depends on the tastes and favorite panelist.

\subsection{Texture}

The results of the analysis of fingerprints against a variety of texture visible comparison of tapioca flour and retention as well as their interaction effect are not real. The highest level of fondness panelist obtained from treatment comparison ratio of flour to 30:70\% with prolonged storage 8 days (6.13) while the lowest score obtained from the comparison of the ratio of tapioca flour,30:70\% with 4 days of retention(5.53) this is due to that the tapioca containing amylopectin starch section where it can provide a good texture to the product produced. While the nature of the starch is easy to inflate in the heat and from gelatinase, so the effect on the texture.

Table 7

The Average Level of Acceptance of Color, Aroma, Flavor, Texture and Overall Acceptance

\begin{tabular}{llllll}
\hline Treatment & Color & Aroma & Taste & Texture & Overall Acceptance \\
\hline $\mathrm{T}_{1} \mathrm{M}_{1}$ & $5.60 \mathrm{c}$ & $5.80 \mathrm{a}$ & $6.46 \mathrm{a}$ & $5.73 \mathrm{a}$ & $6.33 \mathrm{a}$ \\
$\mathrm{T}_{1} \mathrm{M}_{2}$ & $5.80 \mathrm{~b}$ & $5.87 \mathrm{a}$ & $5.93 \mathrm{~b}$ & $5.67 \mathrm{a}$ & $6.20 \mathrm{a}$ \\
$\mathrm{T}_{1} \mathrm{M}_{3}$ & $5.87 \mathrm{a}$ & $5.80 \mathrm{a}$ & $6.00 \mathrm{~b}$ & $5.67 \mathrm{a}$ & $6.33 \mathrm{a}$ \\
$\mathrm{T}_{1} \mathrm{M}_{4}$ & $5.93 \mathrm{a}$ & $5.80 \mathrm{a}$ & $6.07 \mathrm{a}$ & $5.87 \mathrm{a}$ & $6.47 \mathrm{a}$ \\
$\mathrm{T}_{2} \mathrm{M}_{1}$ & $5.87 \mathrm{a}$ & $5.67 \mathrm{a}$ & $6.20 \mathrm{a}$ & $5.93 \mathrm{a}$ & $6.27 \mathrm{a}$ \\
$\mathrm{T}_{2} \mathrm{M}_{2}$ & $5.93 \mathrm{a}$ & $6.20 \mathrm{a}$ & $6.33 \mathrm{a}$ & $5.53 \mathrm{a}$ & $6.47 \mathrm{a}$ \\
$\mathrm{T}_{2} \mathrm{M}_{3}$ & $6.00 \mathrm{a}$ & $5.87 \mathrm{a}$ & $6.40 \mathrm{a}$ & $5.67 \mathrm{a}$ & $6.60 \mathrm{a}$ \\
$\mathrm{T}_{2} \mathrm{M}_{4}$ & $6.00 \mathrm{a}$ & $6.20 \mathrm{a}$ & $6.73 \mathrm{a}$ & $6.13 \mathrm{a}$ & $6.67 \mathrm{a}$ \\
$\mathrm{T}_{3} \mathrm{M}_{1}$ & $5.80 \mathrm{~b}$ & $5.60 \mathrm{a}$ & $6.33 \mathrm{a}$ & $5.80 \mathrm{a}$ & $6.13 \mathrm{a}$ \\
$\mathrm{T}_{3} \mathrm{M}_{2}$ & $5.80 \mathrm{~b}$ & $5.73 \mathrm{a}$ & $6.20 \mathrm{a}$ & $5.93 \mathrm{a}$ & $6.07 \mathrm{a}$ \\
$\mathrm{T}_{3} \mathrm{M}_{3}$ & $5.93 \mathrm{a}$ & $5.73 \mathrm{a}$ & $6.20 \mathrm{a}$ & $6.00 \mathrm{a}$ & $6.27 \mathrm{a}$ \\
$\mathrm{T}_{3} \mathrm{M}_{4}$ & $6.00 \mathrm{a}$ & $5.87 \mathrm{a}$ & $6.27 \mathrm{a}$ & $6.00 \mathrm{a}$ & $6.20 \mathrm{a}$ \\
\hline
\end{tabular}

\subsection{Overall Acceptance}

The results of the analysis of the whole range of prints against the receipt looks and tapioca flour comparison of retention as well as the interaction between this two different treatment towards the overall acceptance are not real chips.

The highest level of panelists favorites gleaned from comparative treatment flour 30\%:70\% with prolonged storage 8 days (6.67), while the lowest score obtained from the comparison of tapioca flour 10\%:90\% with prolonged storage 4 days (6.07). Comparison of treatment of wheat flour and tapioca flour and prolonged storage has no effect on the overall acceptance rate of chips leaves beluntas produced, it is likely this is because the overall acceptance of chips leaves beluntas is very concerned with the results of the panelists overall against the color, aroma, taste, and texture so that leaves beluntas chips are still favored by panellists.

\section{Conclusion}

The chips are produced from the leaves of beluntas research has the characteristics of water content $17.05-25.82 \%$, carbohydrate levels $6.42-11.86 \%$, Protein $2.39-2.73 \%$, Fat content $18.9-23.9 \%$, 
the levels of total phenols $958.71-1485.33 \mathrm{mg} / \mathrm{kg}$, a rate of antioxidant $0.056-0.113 \%$, while from research organoleptic 6.0-6.7 results obtained with criteria love-love. Characteristics of the chips beluntas leaves can still be maintained with tapioca flour: comparison of 30:70 at 8 days storage with objective observations of water levels $(21.50 \%$, carbohydrates, proteins $8.74 \% 2.73 \%, 18.90 \%$, fat levels of phenol $1485.33 \mathrm{mg} / \mathrm{kg}$ drag power antioxidant $0.06 \%$ ). While the subjective observations (color, aroma, flavor, texture and overall admissions) 6.0- 6.7 with criteria like-love.

From this research could be recommended, further research needs to be done to reduce water levels in the beluntas leaf chips still high so that the characteristics of the flaky beluntas leaves can be maintained longer.

\section{References}

[1] Dalimarta, S. (1999). Atlas Tumbuhan Obat Indonesia jilid 2. Trubus Agriwidya xviii. Jakarta.

[2] Fatriani Y. (2003). Evaluasi Penambahan Tepung Tapioka dan Es Batu pada Berbagai Tingkat yang Berbeda terhadap Kualitas Bakso Sapi. Skripsi. Fakultas Peternakan. Institut Pertanian Bogor.

[3] Sulistyowati, A. (2004). Membuat Kripik Buah dan Sayur. Puspa Swara. Jakarta.

[4] Soeparno (1992). Ilmu dan Teknologi Daging. Universitas Gajah Mada Press. Yogyakarta.

[5] Susanti L., Zuki, M. \& Meilita (1993). Kajian Organoleptik, Kimia dan Fisik Kerupuk Dengan Penambahan Tepung Tulang Ikan Tenggiri. Jurnal A groekologi. Vol. 25 No. 2.

[6] Sundari D., Nuratmi, M.B., \& Winarno, W. (2009). Toksisitas Akut (LD 50) dan Uji Gelagat Ekstrak Daun Teh Hijau (Camelia sinensis (Linn) Kunze) pada Mencit. Media Penelitian dan Pengembangan Kesehatan. Vol.XIX (4).

[7] Winarno, F.G. \& Rahayu T.S. (1994). Bahan Tambahan Untuk Makanan dan Kontaminasi. Pustaka Sinar Harapan. Jakarta.

[8] Yudiono, K. (2011). Ekstraksi Antosianin dari Ubi Jalar Ungu (Ipomea batatas ev. Ayamurasaki) dengan Teknik Ekstraksi Subcritical Water. Jurnal Teknologi Pangan. vol. 2 No.1 Nov. 2011. Univ. Katholik Widya Karya Malang. 